ISSN: 2348-1900

Plant Science Today

http://www.plantsciencetoday.online

Mini Review

\title{
Molecular markers assisted DNA polymorphism: Implications in mangrove research
}

\author{
Nirjhar Dasgupta, Anjan Hazra, Sabyasachi Bhattacharya and Sauren Das*
}

Agricultural and Ecological Research Unit, Indian Statistical Institute, 203, Barrackpore Trunk Road, Kolkata 700108, India

\section{Article history}

Received: 11 September 2017

Accepted: 07 October 2017

Published: 16 October 2017

(C) Dasgupta et al. (2017)

Editor

K K Sabu

\section{Publisher}

Horizon e-Publishing Group

Correspondence

Sauren Das

$\triangle$ sauren@isical.ac.in

\begin{abstract}
Mangroves are defined as woody, evergreen group of plant community; grow on the swampy substrate at tropical and sub-tropical habitats, adjusted to high salinity, periodical tidal influence, strong winds, high temperatures, high precipitation and anaerobic soils. They possess unique morphological and physiological adaptive features to cope with these extreme conditions. Mangrove vegetation is the cradle of several marine fauna and provides first line of defense against devastating sea surges, typhoon, tsunami, etc. However, since industrial era, many of the mangrove members were affected by several environmental constrains and anthropogenic activities that raised the sea level, lowered sweet water influx from the adjacent rivers and encroachment for the new settlement formation, increasing salinity. Hence, mangrove restoration program is the front line topic of interest to the plant biologists across the tropical and subtropical world since it has a productive and protective role for the inhabitants. A detailed study of DNA polymorphism of the individual taxa will be provide an advantage for this initiative as the wide genetic plasticity is a prerequisite for sustainability in changed environment. Recent advancement in molecular markers assisted PCR technique will provide the information regarding genetic background of each individual taxon, ultimately leading to valid guided references towards the understanding the inherent nature of the plant itself and beneficial to proper restoration program.
\end{abstract}

Keywords

DNA polymorphism; isozyme; mangroves; molecular markers; PCR technique

\section{Citation}

Dasgupta N, Hazra A, Bhattacharya S, Das S. Molecular markers assisted DNA polymorphism: Implications in mangrove research. Plant Science Today 2017;4(4):166-171. doi: 10.14719/pst.2017.4.4.349

\section{Introduction}

Mangroves are an assemblage of plant community of several unrelated genera which are well adopted in hostile environment like high substrate salinity, periodic inundation, maximum precipitation and high irradiance. They are best suited in the swampy estuaries of the tropical and subtropical world. The Indo-Malaysian area has the highest mangrove population, as this zone is the cradle of initial mangrove formation, which later spread across the tropical and sub-tropical world over the time scale (1). According to a report (2) total mangrove coverage in the world is approximately $137,760 \mathrm{~km}^{2}$, 
among which $60 \%$ coverage is in Asia. Mangrove provides immense support, both ecological and economical, for the fauna as well as human settlements in the coastal areas all over the globe. Their total worth including the commercial importance, timber and plant products, coastal protection, biodiversity and tourism is estimated at \$ 186 million per year approximately (3). Mangroves, due to their dense population, acts as the primary guard against sea surges, storms; which was evident during 2004 Tsunami in some of the Asian countries (4). But due to some natural edaphic factors and different anthropogenic activities, the mangrove forests all over the globe are decreasing at an alarming level. According to a report, the mangrove forest area loss in the south Asia is approximately 1\% every year (5). Sea level rise and increase in substrate salinity are the two major abiotic factors initiating the natural depletion of mangroves all over the world $(6,7)$.

Sundarbans, being the overlapping border of two countries, India and Bangladesh, is the largest continuous stretch of mangrove vegetation (2152 $\mathrm{km}^{2}$ ) in the world (8). This forest also reports the highest species richness in the world comprising of 36 true mangroves, 28 associate and 7 obligatory mangroves which represents 29 families and 49 genera (9). Adaptability to high saline environment varies to a great extent among the different genera. As such, due to various natural and anthropogenic activities salinity of Indian Sundarbans is increasing rapidly and it reaches up to 27 parts-per-thousand (ppt) $(10,11)$. This phenomenon is proving to be lethal for some of the important mangrove species, like Aegialitis rotundifolia, Xylocarpus granatum, $X$. mekongensis, Nypa fruticans and Heritiera fomes $(12,13)$.

\section{Molecular markers and their implication}

Various morphological, anatomical, physiological and molecular characteristics are being used to study the differential adaptability of a species, and molecular markers have an edge over its counterparts as it is not influenced by environmental factors (14). Genetic plasticity has a key role in any species to cope up with the changing environments or sustainability $(15,16)$. A species with high genetic diversity has always more probability to adapt to hostile or rapid changing surroundings, than a species with reduced genetic diversity (17). Molecular marker mediated PCR based study of DNA polymorphism is considered as a prime utility tool for understanding the genetic background of a plant, leading to undertake efficient regeneration or restoration program.

Mangroves doesn't represent a single genetic group, rather they represent the convergent genetic adaptation of a large number of plant families to a specific environment. Because of their uniqueness, physiological, floristic, ecological and taxonomic studies have been reported on Mangrove plant community's time to time (18-20). The development of molecular methods has offered opportunities to develop mangrove research in new directions and also to address unsolved problems of salt management in mangrove studies. Molecular markers can be broadly classified into two ways, PCR based (e.g. Inter Simple Sequence Repeats (ISSR), Random amplified Polymorphic DNA (RAPD)) and based on hybridization (e.g. Restriction Fragment Length Polymorphism (RFLP)). The simplicity in use, low cost, no prior information of DNA sequence and requirement of small amount of DNA, make RAPD marker considered as the most basic and widely used among the all molecular markers assisted study along with ISSR (21). Molecular markers may be dominant and co-dominant, where in dominant markers can only generate information about the presence or absence of a specific trait or loci and co-dominant markers can provide higher level of resolution and information per locus.

\section{Contributions of Molecular Markers for the Mangrove Research \\ Codominant Markers}

Isozymes: Peroxidase (PRX), Superoxide Dismutase (SOD) and Catalase are antioxidant enzymes which play major role in combating stressful environment apart from plant growth and development. Cheeseman et al. (22) found the ascorbate peroxidase and SOD synthesis to be relatively higher in field-grown mangroves. Ge and Sun (23) reported a reduced genetic polymorphism both at inter and intra population level, as revealed by Isozymes analysis, in the mangrove species Kandelia candel. While studying the suitability of peroxidase enzyme as an indicator of heavy metal accumulation in plants, Macfarlane and Burchett (24) reported that the leaf tissue metal concentrations and Peroxidase activity created a positive linear relationship in Avicennia marina (24). Ye, Tam (25) reported that the level of PRX and SOD increased during water logging stress in Kandelia candel and Bruguiera gymnorrhiza. Parida $(26,27)$ reported differential changes in the levels of various antioxidant enzymes in an in vitro experiment with varied $\mathrm{NaCl}$ treatment on Bruguiera parviflora, indicating towards the antioxidant enzymes being a potential marker for salt tolerance in mangroves. The authors commented that the high levels of the antioxidant enzymes enhanced the defensive ability of the plants against reactive oxygen species (ROS) which in turn avoids lipid peroxidation during salt stress. Dasgupta et al. (7, 28) worked with some mangrove species from Indian Sundarbans and reported an increase in concentration of two antioxidant enzymes PRX and SOD; and two stress-related hydrolyzing enzymes, Acid phosphatase and Esterase with the 
rise of salinity in in situ condition. Qualitative study with gel electrophoresis also indicated the density and/or number of bands increase (isoforms) for all the four enzymes with increased salinity. They also reported decrease in the concentration of total protein with salinity hike, as the high molecular weight proteins get degraded to produce low molecular weight proteins which need to be accumulated in the cell sap to restore the required osmotic potential $(\Psi)$ during salt stress.

RFLP: Restriction Fragment Length Polymorphism (RFLP) is a non PCR based molecular marker, in which the DNA is digested with restriction enzymes and the resulting fragments are separated depending on their molecular weight in agarose gel electrophoresis. Parani et al. (29) had reported $66 \%$ variation in Avicennia marina, collected from two different locations and described it as high degree of divergence among the populations. Later, Parani et al. (30) had also reported a high level of intra-specific as well as inter-generic genetic diversity in 11 true mangroves, 3 true minor mangroves and 2 mangrove associates. Moreover, the genetic diversity of Avicennia marina was reported to be higher among 24 true mangroves and mangrove associates using PCR based RFLP of trnS-psbC and $r b c L$ gene regions using HaeIII restriction enzyme (31) and showed Intra-generic variation in mangrove genera Avicennia, Suaeda and Rhizophora.

SSR: Simple Sequence Repeats (SSR) or Microsatellite is a stretch of DNA in which a specific motif, usually 3 to 5 nucleotide long is repeated 5-50 times (32). Their abundance in genome as well as high mutation rates has made them the codominant markers of choice for studying genetic diversity. The initial cost is high as it involves sequencing the PCR products, but once the loci are selected, it is highly reproducible. ISSR on the other hand, is the region flanking the microsatellite loci. They are more reproducible than RAPD and their cost is less than AFLP. Maguire, Peakall (33) studied Avicennia marina and reported higher level of genetic polymorphism using SSR marker than AFLP. Intra and interspecific genetic polymorphism of 10 mangrove and non-mangrove populations of Heritiera littoralis from three sites of China and one site of Australia using ISSRs was reported by Jian et al. (34). Chen et al. (35) developed and characterized 9 SSR markers for the mangrove species Sonneratia caseolaris. Jian et al. (36) reported reduced level of SSR polymorphism in their study in Nypa fruticans collected from six natural populations in China, Thailand and Vietnam.

\section{Dominant Markers}

RAPD: This is relatively the most basic and quick PCR based technique for assessing the genetic diversity. Parani et al. (29) reported both intra- as well as interspecific genetic variability in the Avicennia genus based on RAPD markers. In another experiment Dasgupta et al. (30) reported $96.5 \%$ similarity of Rhizophora apeculata and $R$. mucronata to that of their hybrids as revealed by RAPD analysis. Intraspecific genetic polymorphism in mangrove species Excoecaria agallocha was reported by Lakshmi et al. (37). Genetic polymorphism of Avicennia alba was tested by Teixeira et al. (38) using 20 primer pairs for 16 individuals from the Mekong Delta, Vietnam. The authors reported satisfactory polymorphism with six primer pairs; while six primer pairs did not produce adequate polymorphism and seven failed to produce any polymorphism. The molecular source of divergence of the species Ceriops zippeliana and $C$. decandra from Southeast Asia using RAPDs was reported by Sheue et al. (39). High level of genetic polymorphism among the Avicenniaceae species i.e. Avicennia marina, A. alba and A. officinalis was also reported by Kader et al. (40). Genetic diversity of Xylocarpus granatum, $X$. moluccensis and $X$. mekongensis collected from different locations of Tamil Nadu and Andhra Pradesh of India was assessed by Pawar et al. (41) using RAPD technique, where they reported low level of genetic similarity between two species $X$. granatum and $X$. mekongensis. Dasgupta et al. $(42,43)$ worked with some Indian mangroves and reported lower level of genetic polymorphism as exists in two plant species Heritiera fomes and Xylocarpus granatum, which are considered to be on the verge of extinction from Indian Sundarbans. On the other hand, relatively higher level of genetic diversity exist among three other taxa, Bruguiera gymnorrhiza, Phoenix paludosa and Excoecaria agallocha; which in turn pointed out to their sustainable existence in the same regime.

ISSR: ISSR is another widely used molecular marker, which has relatively higher reproducibility than RAPD molecular markers (44). $\mathrm{Li}$ and Chen (45) reported a high genetic polymorphism value of $77.44 \%$ while estimating the genetic diversity of Sonneratia alba from China using ISSR marker. Tan et al. (46) used ISSR marker to assess the genetic diversity in populations of a mangrove Ceriops decandra collected from 10 different locations in Malay Peninsula and North Australia. Genetic diversity of Lumnitzera racemosa and Lumnitzera littorea (Combretaceae), an endangered mangrove as reported by Su et al. $(47,48)$ from the Indo West Pacific zone used ISSR marker. High level of diversity was reported at the intraspecific level, leading to be focused on planning a proper conservation strategy for this species. Chen et al. (49) assessed the genetic diversity of 7 populations of Kandelia obovata from China using ISSR 
marker. Dasgupta et al. $(42,43)$ reported relatively higher level of ISSR polymorphism in Bruguiera gymnorrhiza, Phoenix paludosa and Excoecaria agallocha, and reduced ISSR polymorphism in Heritiera fomes and Xylocarpus granatum expressing feebler adaptability than those of earlier taxa.

AFLP: Amplified Fragment Length Polymorphism (AFLP) is a popular molecular marker in which the DNA is digested with Restriction enzymes which is followed by PCR amplification. Maguire et al. (33) commented that AFLPs to be competent at revealing polymorphic loci, despite of their lower average heterozygosity. Mukherjee et al. (50) used AFLP markers to perform molecular characterization of three Heritiera species. These authors postulated that Heritiera littoralis is better suited as an associate mangrove than a true one. Giang et al. (51) reported a high level of polymorphism in Avicennia marina collected from coastal area of Vietnam. Genetic diversity of Merope angulate, a mangrove associate was assessed by Jena et al. (52) The authors reported low level of genetic polymorphism as revealed by AFLP among the samples collected from two different mangrove forests in India.

\section{Future Prospects}

The molecular level study of the Mangrove Genetics is still at very initial stage. Although some work on the molecular characterization of mangroves is being done in different parts of the world, the information available is still very limited. Adequate molecular data is a primary prerequisite for preparing the proper conservation strategies for mangrove species. Quantitative real time PCR analyses of the different mangrove taxa collected from different saline zones can provide important information regarding the differential adaptive features of the plant species. With the recent development of Next Generation Sequencing it will be possible to generate a huge amount of data, regarding functional genomics, Expressed Sequence Tags (ESTs), Single Nucleotide Polymorphism (SNP) etc., if proper initiatives are taken into account. This technique of research would be highly beneficial for mangrove research, in order to understand the differential salt management ability of different taxa leading to proper restoration and Conservation strategy.

\section{Acknowledgement}

ND is thankful to Science and Engineering Research Board (SERB) for providing NPDF.

\section{Competing interests}

The authors declare that they have no competing interests.

\section{Authors contributions}

ND begin the work and carried out manuscript writing. SS and $\mathrm{AH}$ contributed in manuscript writing. SD contributed in manuscript writing, corrections and final checking.

\section{References}

1. Alongi D. The energetics of mangrove forests: Springer Science \& Business Media; 2009.

2. Giri C, Ochieng E, Tieszen LL, Zhu Z, Singh A, Loveland $\mathrm{T}$, et al. Status and distribution of mangrove forests of the world using earth observation satellite data. Global Ecology and Biogeography 2011;20(1):154-9. doi: 10.1111/j.14668238.2010.00584.x

3. Food and Agricultural Organization UNF. The World's Mangroves 1980 - 2005. Rome: FAO; 2007.

4. Giri C, Zhu Z, Tieszen L, Singh A, Gillette S, Kelmelis J. Mangrove forest distributions and dynamics (1975-2005) of the tsunami-affected region of Asia. Journal of Biogeography 2008;35(3):519-28. doi: 10.1111/j.1365-2699.2007.01806.x

5. Giri C, Long J, Abbas S, Murali RM, Qamer FM, Pengra B, et al. Distribution and dynamics of mangrove forests of South Asia. Journal of environmental management 2015;148:101-11. doi: 10.1016/j.jenvman.2014.01.020

6. Gilman EL, Ellison J, Duke NC, Field C. Threats to mangroves from climate change and adaptation options: a review. Aquatic botany 2008;89(2):23750. doi: 10.1016/j.aquabot.2007.12.009

7. Dasgupta N, Nandy P, Sengupta C, Das S. Protein and enzymes regulations towards salt tolerance of some Indian mangroves in relation to adaptation. Trees 2012;26(2):377-91. doi: 10.1007/s00468-0110599-x

8. India FSo. State forest report 2009. Ministry of Environment and Forests, Government of India. 2009. $226 \mathrm{p}$.

9. Naskar K, Guha Bakshi D. A brief review on some less familiar plants of the Sundarbans. Journal of Economic and Taxonomic Botany 1983;4(3):699711.

10. Nandy P, Dasgupta N, Das S. Differential expression of physiological and biochemical characters of some Indian mangroves towards salt tolerance. Physiology and Molecular Biology of Plants 2009;15(2):151-60. doi: 10.1007/s12298-009-0017-7

11. Dasgupta N, Nandy P, Das S. Photosynthesis and antioxidative enzyme activities in five Indian mangroves with respect to their adaptability. Acta physiologiae plantarum 2011;33(3):803-10. doi: 10.1007/s11738-010-0605-8

12. Banerjee LK. Mangroves of Orissa coast and their ecology: Bishen Singh Mahendra Pal Singh; 1990.

13. IUCN 2017. IUCN Red List of Threatened Species. Ver. 2017-2. Available from: www.iucnredlist.org.

14. Winter P, Kahl G. Molecular marker technologies for plant improvement. World Journal of Microbiology and Biotechnology 1995;11(4):438-48. doi: 10.1007/BF00364619

15. Schaal B, Leverich WJ, Rogstad S. Comparison of methods for assessing genetic variation in plant conservation biology. Genetics and conservation of rare plants 1991:123-34. 
16. Govindaraj M, Vetriventhan M, Srinivasan M. Importance of genetic diversity assessment in crop plants and its recent advances: an overview of its analytical perspectives. Genetics research international 2015;2015. Article ID 431487. doi: 10.1155/2015/431487

17. Ayala FJ, Kiger Jr JA. Modern Genetics. 1984. Second Edition. - London, Amsterdam, Ontario, Sydney: The Benjamin/Cummings Publishing Company, Inc.

18. Weber-El Ghobary MO. The systematic relationships of Aegialitis (Plumbaginaceae) as revealed by pollen morphology. Plant Systematics and Evolution 1984;144(1):53-8. doi: 10.1007/BF00990800

19. Juncosa A, editor Floral development and character evolution in Rhizophoraceae. Aspects of floral development Proceedings of the double symposium'Floral development: evolutionary aspects and special topics', held at the XIV International Botanical Congress, Berlin (West), Germany, July; 1988.

20. Das S. An adaptive feature of some mangroves of Sundarbans, West Bengal. Journal of Plant Biology 1999;42(2):109-16. doi: 10.1007/BF03031018

21. Khaled A, Motawea M, Said A. Identification of ISSR and RAPD markers linked to yield traits in bread wheat under normal and drought conditions. Journal of Genetic Engineering and Biotechnology 2015;13(2):243-52. doi: 10.1016/j.jgeb.2015.05.001

22. Cheeseman J, Herendeen L, Cheeseman A, Clough B. Photosynthesis and photoprotection in mangroves under field conditions. Plant, Cell \& Environment 1997;20(5):579-88. doi: 10.1111/j.13653040.1997.00096.x

23. Ge X, Sun M. Reproductive biology and genetic diversity of a cryptoviviparous mangrove Aegiceras corniculatum (Myrsinaceae) using allozyme and intersimple sequence repeat (ISSR) analysis. Molecular Ecology 1999;8(12):2061-9. doi: 10.1046/j.1365-294x.1999.00821.x

24. Macfarlane G, Burchett M. Photosynthetic pigments and peroxidase activity as indicators of heavy metal stress in the grey mangrove, Avicennia marina (Forsk.) Vierh. Marine Pollution Bulletin. 2001;42(3):233-40. doi: 10.1016/S0025326X(00)00147-8

25. Ye Y, Tam NF, Wong Y, Lu C. Growth and physiological responses of two mangrove species (Bruguiera gymnorrhiza and Kandelia candel) to waterlogging. Environmental and Experimental Botany 2003;49(3):209-21. doi: 10.1016/S00988472(02)00071-0

26. Parida AK, Das AB, Mohanty P. Investigations on the antioxidative defence responses to $\mathrm{NaCl}$ stress in a mangrove, Bruguiera parviflora: differential regulations of isoforms of some antioxidative enzymes. Plant Growth Regulation 2004;42(3):21326.doi: 10.1023/B:GROW.0000026508.63288.39

27. Parida AK, Das AB, Mohanty P. Defense potentials to $\mathrm{NaCl}$ in a mangrove, Bruguiera parviflora: differential changes of isoforms of some antioxidative enzymes. Journal of plant physiology 2004;161(5):531-42. doi: 10.1078/0176-1617-01084

28. Dasgupta N, Nandy P, Tiwari C, Das S. Salinityimposed changes of some isozymes and total leaf protein expression in five mangroves from two different habitats. Journal of Plant Interactions 2010;5(3):211-21. doi: 10.1080/17429140903438076

29. Parani M, Rao CS, Mathan N, Anuratha CS, Narayanan KK, Parida A. Molecular Phylogeny of mangroves III Parentage analysis of a Rhizophora hybrid using random amplified polymorphic DNA and restriction fragment length polymorphism markers. Aquatic Botany 1997;58(2):165-72. doi: 10.1016/S0304-3770(97)00003-X

30. Parani M, Lakshmi M, Senthilkumar P, Ram N, Parida A. Molecular phylogeny of mangroves V. Analysis of genome relationships in mangrove species using RAPD and RFLP markers. Theoretical and Applied Genetics 1998;97(4):617-25. doi: 10.1007/s001220050937

31. Parani M, Lakshmi M, Ziegenhagen B, Fladung M, Senthilkumar P, Parida A. Molecular phylogeny of mangroves VII. PCR-RFLP of trnS-psbC and rbcL gene regions in 24 mangrove and mangroveassociate species. Theoretical and Applied Genetics 2000;100(3):454-60. doi: 10.1007/s001220050059

32. Turnpenny PD, Ellard S. Emery's Elements of Medical Genetics (2nd Edition): Elsevier Health Sciences; 2005.

33. Maguire T, Peakall R, Saenger P. Comparative analysis of genetic diversity in the mangrove species Avicennia marina (Forsk.) Vierh. (Avicenniaceae) detected by AFLPs and SSRs. Theoretical and Applied Genetics 2002;104(2):38898. doi: $10.1007 / \mathrm{s} 001220100724$

34. Jian S, Tang T, Zhong Y, Shi S. Variation in intersimple sequence repeat (ISSR) in mangrove and non-mangrove populations of Heritiera littoralis (Sterculiaceae) from China and Australia. Aquatic Botany 2004;79(1):75-86. doi: 10.1016/j.aquabot.2004.01.005

35. Chen T, Zhou R, Ge X-J, Shi S. Development and characterization of microsatellite markers for a mangrove tree species Sonneratia caseolaris (L.) Engler (Lythraceae sensu lato). Conservation Genetics 2008;9(4):957-9. doi: 10.1007/s10592-0079404-1

36. Jian S, Ban J, Ren H, Yan H. Low genetic variation detected within the widespread mangrove species Nypa fruticans (Palmae) from Southeast Asia. Aquatic Botany 2010;92(1):23-7. doi: 10.1016/j.aquabot.2009.09.003

37. Lakshmi M, Parani M, Ram N, Parida A. Molecular phylogeny of mangroves VI. Intraspecific genetic variation in mangrove species Excoecaria agallocha L. (Euphorbiaceae). Genome 2000; 43(1):110-5. doi: 10.1139/g99-109

38. Teixeira S, Arnaud-Haond S, Duarte C, Serrão E. Polymorphic microsatellite DNA markers in the mangrove tree Avicennia alba. Molecular Ecology Resources 2003;3(4):544-6. doi: 10.1046/j.14718286.2003.00505.x

39. Sheue CR, Liu HY, Tasi CC, Rashid SMA, Yong JWH, Yang YP. On the morphology and molecular basis of segregation of two species Ceriops zippeliana Blum. and $C$. decandra (Griff.) Ding Hou (Rhizophoraceae) from Southeastern Asia. Blumea 2009;54 220-7. doi:10.3767/000651909X476193

40. Kader A, Sinha S-N, Ghosh P. Evaluation of genetic diversity of Avicenniaceae family in Indian sundarban by using RAPD and ISSR markers. 
Iranian Journal of Genetics and Plant Breeding 2012;1(2):22-7.

41. Pawar UR, Baskaran J, Ajithkumar IP, Panneerselvam R. Genetic variation between Xylocarpus spp.(Meliaceae) as revealed by random amplified polymorphic DNA (RAPD) markers. Emirates Journal of Food and Agriculture. 2013;25(8):597.

42. Dasgupta N, Nandy P, Sengupta C, Das S. Genetic variation in relation to adaptability of three mangrove species from the Indian Sundarbans assessed with RAPD and ISSR markers. Journal of Forestry Research 2017;1-10. doi: 10.1007/s11676017-0467-7

43. Dasgupta N, Nandy P, Sengupta C, Das S. RAPD and ISSR marker mediated genetic polymorphism of two mangroves Bruguiera gymnorrhiza and Heritiera fomes from Indian Sundarbans in relation to their sustainability. Physiology and Molecular Biology of Plants 2015;21(3):375-84. doi: 10.1007/s12298-015-0308-0

44. Triest L. Molecular ecology and biogeography of mangrove trees towards conceptual insights on gene flow and barriers: A review. Aquatic Botany 2008;89:138-54. doi: 10.1016/j.aquabot.2007.12.013

45. Li H-S, Chen G-Z. Genetic diversity of Sonneratia alba in China detected by inter-simple sequence repeats (ISSR) analysis. Acta Botanica Sinica 2004;46(5):515-21. www.chineseplantscience.com

46. Tan F, Huang Y, Ge X, Su G, Ni X, Shi S. Population genetic structure and conservation implications of Ceriops decandra in Malay Peninsula and North
Australia. Aquatic Botany 2005;81(2):175-88. doi: 10.1016/j.aquabot.2004.11.004

47. Su G, Huang Y, Tan F, Ni X, Tang T, Shi S. Conservation genetics of Lumnitzera littorea (Combretaceae), an endangered mangrove, from the Indo-West Pacific. Marine biology 2007;150(3):321-8. doi: 10.1007/s00227-006-0357-6

48. Su G-H, Huang Y-L, Tan F-X, Ni X-W, Tang T, Shi S$\mathrm{H}$. Genetic variation in Lumnitzera racemosa, a mangrove species from the Indo-West Pacific. Aquatic Botany 2006;84(4):341-6. doi: 10.1016/j.aquabot.2006.01.001

49. Chen M, Tan Z, Zeng G, Peng J. Comprehensive analysis of simple sequence repeats in pre-miRNAs. Molecular biology and evolution 2010;27(10):222732. doi: $10.1093 / \mathrm{molbev} / \mathrm{msq} 100$

50. Mukherjee A, Acharya L, Mattagajasingh I, Panda P, Mohapatra T, Das P. Molecular characterization of three Heritiera species using AFLP markers. Biologia plantarum 2003;47(3):445-8. doi: 10.1023/B:BIOP.0000023892.82238.f8

51. Le HG, Hong PN, Tuan MS, Harada K. Genetic variation of Avicennia marina (Forsk.) Vierh. (Avicenniaceae) in Vietnam revealed by microsatellite and AFLP markers. Genes \& genetic systems 2003;78(6):399-407. doi: 10.1266/ggs.78.399

52. Jena SN, Verma S, Nair KN, Srivastava AK, Misra S, Rana TS. Genetic diversity and population structure of the mangrove lime (Merope angulata) in India revealed by AFLP and ISSR markers. Aquatic Botany 2015;120:260-7. doi: 10.1016/j.aquabot.2014.09.004 